\section{TRANSFORMATIONAL LEADERSHIP, PROCEDURAL JUSTICE, AND EMOTION OF INDONESIA CIVIL STATE APPARATUS: DOES IT MATTER?}

\author{
Shine Pintor* \\ Universitas Terbuka, Indonesia \\ Maylitha Achmad \\ Puslatbang KMP LAN
}

\section{Transformational Leadership, \\ Procedural Justice, and Emotion of Indonesia Civil State Apparatus: Does It Matter?}

\begin{abstract}
This study aims to uncover the effect of transformational leadership toward procedural justice and its impact on the positive emotions of the Indonesia Civil State Apparatus (CSA). This study involved respondents which are in Jakarta, Makassar, Palu, and Ambon. As far as we know, the perceptions of transformational leadership and procedural justice in the government environment can be variably different by each employee. Thus, this will tend to affect positive emotions. To prevent the bias response, the Social Desirability Response (SDR) test was conducted. The sample size in this study was 572 respondents. A purposive sampling technique was used to gain respondents. This study gave a piece of evidence that transformational leadership in government agencies could explain and predict procedural justice which is perceived by CSA. Subsequently, procedural justice could affect CSA positive emotions. This study proved that transformational leadership could explain and predict organizational citizenship behavior.
\end{abstract}

Keywords: Leadership; Transformational; Justice; Procedural; SDR
Received June $7^{\text {th }} 2021$

Review

September $16^{\text {th }} 2021$

Publish

December $1^{\text {st }} 2021$

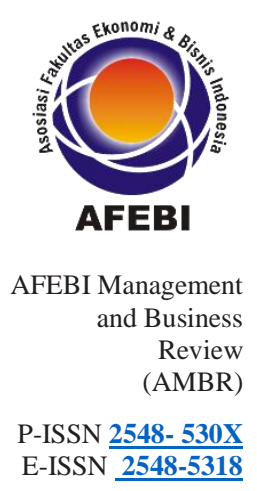

*Corresponding author. Email address: shinepintor@ecampus.ut.ac.id 
Human resources are one of the important assets in the organization, both business and government organizations. They have a role as subjects to implement policies and activities in the organization. Without them and their performance, organizational resources such as capital, methods, and machines will not work for optimal results (Wright and Pandey, 2010).

Based on the literature on leadership, Ingraham and Getha-Taylor (2004) argued that transformational leadership is very important to pursue organization effectiveness, and government organizations are no exception. This type of leadership will create a positive culture, strengthen motivation, clarify the mission and goals, and bring the organization to gain productive and high-performance outcomes (Ingraham and Getha-Taylor, 2004).

Furthermore, leadership factors determine the success or failure of carrying out its organization operations. So, the capacity of government organizations should give a supporting toward the implementation of good governance. However, according to Thoha (2008) weaknesses of leadership is one of the so many factors which caused the fault of bureaucratic performance in Indonesia.

This is in line with the argument proposed by Crosby and Bryson (2018). They argued that many studies of leadership in government organizations domain, always merely focused on transformational leadership and transactional leadership. This is because there are always exchange relationships between superiors and subordinates in government organizations so fellow employees created affection and motivation (Crosby and Bryson, 2018).

Furthermore, the real phenomena in the organization are indicated by different perspectives between employees with other employees regarding organizational justice. As an example: the treatment of leaders to subordinates, the provision of wages or policies which are given, etc. Thus, according to Colquitt et al (2001), there are several kinds of organizational justice perceived by an employee, namely the distribution of rewards or incentives, the allocation process, and how to treat them in the organization.

Budiyanti et al (2018) proved, there are always organizational injustices in government organizations perceived by subordinates. This is caused by leader behavior to treat subordinates and subsequently affect positive and negative emotions (Budiyanti et al., 2018). Generally, this phenomenon is caused by several factors, such as the distribution of official travel and incentive activities (Budiyanti et al., 2018). As a result, it will affect positive and negative emotions of the civil state apparatus which subsequently impact job satisfaction (Budiyanti et al., 2018).

Moreover, many studies have shown that leadership and justice have an important effect on the organization (Wang et al., 2010; Guh et al., 2013; Chen and Jin, 2014; Kim et al., 2017; Unterhitzenberger and Bryde, 2019). Furthermore, Iqbal et al. (2018) argued that organizational justice has a significant effect on leadership in the organization. In line with Iqbal et al. (2018), Sharma (2016) also argued by giving an opinion, that managers should realize the importance of organizational justice because it could prevent refusing and being boycotted by their subordinates. Furthermore, Chen et al. (2018) also argued, in the context of social exchange, leadership and organizational justice could affect organizational citizenship behavior.

According to Colquitt et al. (2001), in the organizational justice domain, several studies shows that justice perception could affect organizational commitment, job satisfaction, turnover intention, organizational citizenship behavior, and job performance. Furthermore, It is also acknowledged that justice can explain and predict emotional responses, especially when an individual perceived injustice (Cohen-Charash and Spector, 2001; Barclay et al., 2005; Cropanzano et al., 2007).

Moreover, other studies show that emotions have a close relationship between injustice experience and tendency to retaliate (Barclay et al., 2005; Tracy et al., 2007; Skarlicki et al., 2008). Furthermore, Cohen-Charash and Spector (2001), Barclay et al (2005), and Cropanzano et al (2007) argued there is a lack of studies that investigate the effect of justice on emotions. Even though, many studies showed that organizational justice which consists of procedural justice, distributive justice, and interactional justice affect emotions and subsequently impact job satisfaction. These studies are conducted by Cohen-Charash and Spector (2001), Rupp et al. (2006), Gotlib (2011), and Mazurkiewicz, (2009). Thus, in government organizations, the empirical evidence showed that civil state apparatus always compares their gaining with their co-worker to ensure that justice has been created. In most organizations, such as government organizations, civil stated apparatus always view that when the leaders treated them fairly, they would feel satisfaction and perceived that organizational justice has been created (Cropanzano et al., 2008).

Based on our initial observations through interviews with 100 civil state apparatus that worked in Jakarta, 73 employees (73\%) were dissatisfied with their leader and 27 employees (27\%) stated that they perceived injustices. Furthermore, also, the initial interview shows that leadership characteristics by civil state apparatus in Indonesian government agencies are transformational behavior. This is because of those leaders whose behavior like the way dare to be open each toward his/her subordinates regarding the operating procedures which carry out activities within the organization. 
The number showed that civil state apparatus in government organizations tend to experience unfair treatment and dissatisfaction with the leader. Based on the results of our initial interview and research conducted by Strom et al. (2014), Wu et al.(2017), and Budiyanti et al. (2018), when subordinate is not allowed to develop competency as a state civil apparatus, they will feel dissatisfied. Moreover, one example regarding the form of injustice is complaining of civil state apparatus regarding the issuance of regulations on cutting performance benefits when they do not come to work even because of illness.

Overall, based on the preliminary observations, it can be presumed that leadership style has a significant effect on organizational citizenship behavior. As argued by Organ (1990) and Podsakoff et al. (2000) that organizational citizenship behavior, as an example: serious, helpful, and responsible; do the assignment beyond the leader's expectations; involved in any extra activities in the organization, and improving aspects of the work even though it is not obligatory. According to this case, good leadership will affect motivation, commitment, subordinate's involvement, job satisfaction, and subordinate's trust toward the leader. Thus, good and appropriate leadership behavior will predict subordinates' positive perceptions regarding organizational justice (Cropanzano et al., 2002; Susanj and Jakopec, 2012).

As one of leadership style, Transformational behavior is important in a government agency, because the organization operate in high risk-averse work environments where mistakes can inflict unintended harm on the most vulnerable populations, which can result in career-ending outcomes (Van Wart, 2003). According to it, for helping executives to manage organizational and personal risks, they often release their span of control and empower their subordinates to make decisions (Van Wart, 2003). While this leadership strategy could be considered transformational, an unintended consequence is a noticeable loss of managerial accountability (McCracken et al., 2012; Srithongrung, 2011). Wright and Pandey (2010) argued when leaders actively empower their subordinates, it raises concerns in the executive ranks that inappropriate decision-making will occur due to failure, accountability, and job loss. This often cause subordinates to feel procedural unfairness which has an impact on their emotions (Trottier et al., 2008; Wright and Pandey, 2010). Therefore, transformational leadership and procedural justice play an important role in forming positive emotions for civil state apparatus who work in government organizations (Trottier et al., 2008; Wright and Pandey, 2010).

According to the results of the initial interview, organizational injustice perceived by the civil state apparatus will affect negative emotions (Barclay et al., 2005; Barclay and Skarlicki, 2009). Negative emotions, such as anger, shame, hostility, and retaliation, would be formed because of injustice perception (Barclay et al., 2005; Barclay and Skarlicki, 2009). This phenomenon is in line with research which is conducted by Morris and Keltner (2000) and Cohen-Charash and Spector (2001). They argued that organizational justice could affect employee emotions, such as delight, angry, and sadness.

The gap of this research is based on research conducted by several researchers such as Susanj and Jakopec (2012), Gillet et al. (2013), and Deschamps et al. (2016). They argued that there is a close relationship between leadership and organizational justice. However, there is a lack of research that linked organizational justice and leadership (Armagan and Erzen, 2015). According to Bass (1995), leadership effectiveness, satisfaction, innovation, quality improvement, performance evaluation both subjectively and objectively and organizational justice could be affected by transformational behavior.

The next gap is regarding emotion as an affection variable. Even though emotions are always discussed in justice theories, there is a still lack of research on organizational justice that accounts for emotions (e.g., Devonish et al., 2012; Barclay and Saldanha, 2015). Likewise, Fambrough and Hart (2008) and Rupp et al (2014) argued, mediating or moderating variables should be stated in the relationship between leadership and emotions. As an example, leader-member exchange and organizational justice. In line with Fambrough and Hart (2008) and Rupp et al (2014), Strom et al. (2014) stated that the formation of employee emotions can be caused by leader characteristics or perceptions of fairness in organizations. Thus, there is a significant correlation between justice and emotions. In line with them, Weiss et al. (1999) argued, emotions could be understood as a special form of the organizational justice evaluation process.

This research concern transformational leadership and procedural justice. The main reason for this is because the civil state apparatus always concerns with transformational leadership which is considered as a capable leadership in providing a sense of justice related to systems and procedures for implementing operational activities in government organizations (Trottier et al., 2008; Wright and Pandey, 2010). As argued by Trottier et al (2008) and Wright and Pandey (2010), further research is needed on transformational leadership and procedural justice that can form positive emotions for civil state apparatus who work in government organizations. Therefore, the objective of this study is to uncover the effect of transformational leadership toward procedural justice and its subsequent impact on positive emotions of Indonesia civil state apparatus.
Transformational Leadership, Procedural Justice, and Emotion of

Indonesia Civil State Apparatus: Does It Matter? 
A transformational leader is someone whose competencies motivate his/her members and pursue the goals of the organization (Bass and Riggio, 2006). Driving subordinates as individuals and teams to work beyond the status quo, and have a clear vision to make various changes in organizational culture is transformational leader characteristics (Northouse, 2016). Transformational leadership is an activity to influence people so that they like to try to achieve group goals. According to Bass and Riggio (2006), transformational leadership is the activity to affect people for working together to achieve their goals.

Furthermore, also, they define that leadership as a form of domination based on personal abilities that can encourage or invite others to do something, based on acceptance by the group and have special skills that are appropriate for special situations.

According to Bass and Avolio (1993), transformational as a leader has the power to affect subordinates in certain ways. Through transformational leadership, subordinates will feel trusted, valued, loyal and respectful to their leaders. Thus, transformational leadership is a leadership style used by a manager when he wants a group to expand and perform beyond the status quo or achieve an entirely new set of organizational goals. Transformational leadership in principle motivates subordinates to do better than what can be done, in other words, it can increase the confidence or self-confidence of subordinates which will affect performance improvement (Yukl, 2013). Idealized influence, Individualized consideration, Inspirational motivation, and Intellectual stimulation are the dimensions of transformational leadership (Yukl, 2013).

\section{Procedural Justice}

Cropanzano et al. (2007; 2008) and Cropanzano and Stein (2009) argued procedural justice is related to the perception of fairness of the procedures used for and the process to arrive at a decision. Fair procedures and processes also tend to moderate the impact of negative reactions arising from decisions that result in undesirable outcomes for workers (Barclay and Skarlicki, 2009). The effect of procedural justice is also known as the effect of a fair process (fair process effect) because the perception of the fairness of the process can have an effect in increasing the acceptance of outcomes even when the outcome has undesirable implications (Barclay and Skarlicki, 2009). The factors that are taken into consideration in a person's assessment of the fairness of a particular process or procedure are grouped twofold, namely: structural and social factors. Procedural justice, namely the fairness of the procedures used to determine the outcomes received by workers is a structural aspect of justice (Barclay and Skarlicki, 2009).

\section{Emotion}

Emotions are defined as reactions to certain situations by the body (Tracy et al., 2007). Things that are usually related to a person's (cognitive) thinking activity, namely the nature and intensity of emotions, are due to the result of the perception of the situation (Tracy et al., 2007).

Emotion is one aspect that has a major influence on human attitudes. This is accompanied by two other aspects, namely the power of thought (cognitive) and psychomotor (conative), usually, emotions are often known as affective aspects, this is from the attitudes determination, which is one of the predispositions of human behavior (Tracy et al., 2007).

\section{The Effect of Transformational Leadership on Procedural Justice}

Empower subordinates, giving individual consideration to subordinates and supporting their ideas are the main characteristics of transformational leadership (Bass and Avolio, 1993). Pillai et al (1999) in their research argued that the outcome of organizational decisions could be affected by subordinates' interests because of a transformational leader.

Furthermore, transformational leaders could motivate subordinates to engage in fair exchange relations between them in an organization (Pillai et al., 1999). Therefore, from this point of view, it forms procedural justice. In other words, subordinates have an opportunity to participate in the decision-making process (Pillai et al., 1999).

Moreover, Selznick in his research argued employee agreement regarding psychological contracts is affected by managerial authority (Folger and Bies, 1989). Thus, subordinates are coincident that their activities are managed by the management (Folger and Bies, 1989). In line with Folger and Bies (1989), Song et al. (2012) and Kim and Kim (2015) argued that allocating process of organizational resources to improve employee skills development comes from or is affected by transformational leadership. Thus, the point is, procedural fairness could be formed by implementing decision-making as managerial responsibility and empower subordinates to participate (Pillai et al., 1999).

H1: Transformational leadership affect procedural justice perception of Indonesia Civil State Apparatus. 
This study is based on the model developed by Mehrabian and Russell (1974) (see: Namkung and Jang, 2010). They argued that environmental stimuli will affect individual emotions which in turn will affect their response in the form of approach or avoidance (Namkung and Jang, 2010). According to it, Bagozzi (1986) states that stimuli are external to people and consist of various physical elements (Namkung and Jang, 2010). Furthermore, organism refers to internal structures and processes that will subsequently intervene in the relationship between external stimuli in people and displayed behavior or responses (Bagozzi, 1986) (see: Namkung and Jang, 2010). This suggests that the impact of a stimulus on human behavior is mediated by emotion. (Namkung and Jang, 2010).

Subordinates would perceive emotions when they are rewarded for his/her job performance, receives a promotion, or receives gratitude from a colleague. Thus, an emotional experience is one of the organizational justice consequences (Cohen-Charash and Spector, 2001; Barclay et al., 2005; Cassar and Buttigieg, 2015). Other studies conducted by Ledimo (2015) and Budiyanti et al. (2018) argued individual emotions could be predicted by procedural justice. Furthermore, the relationship between perceived organizational justice and actions to take revenge could be mediated by employee emotions (Cassar and Buttigieg, 2015). Cassar and Buttigieg (2015) argued that psychological contracts breach mediate the relationship of organizational justice and emotions. Dzansi (2016) shows that perceived organizational justice affects the quality of services provided by employees. In line with him, Moon (2017) argued that procedural justice could affect positive emotions. Thus, the second hypothesis in this study is:

$\mathrm{H} 2$ : Procedural justice affects positive emotions perception of Indonesia civil state apparatus.

Thus, based on the main objective of this study, the theoretical models proposed in this study are as follow:

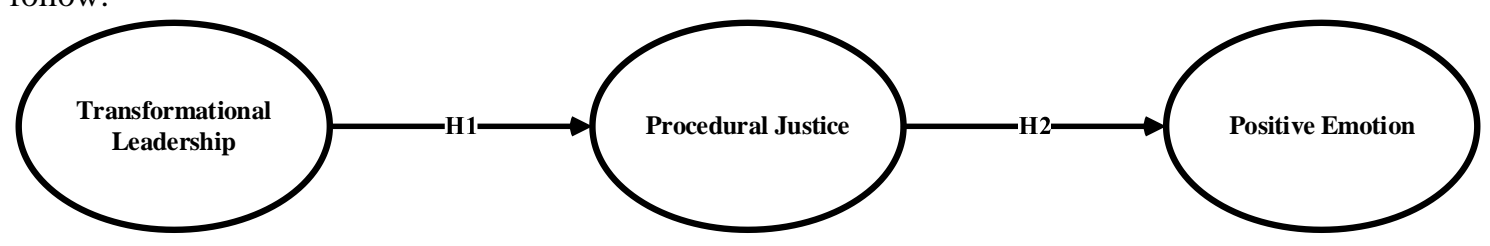

\section{RESEARCH METHODOLOGY}

A questionnaire was developed as a tool for gaining information through survey methods. The questionnaire was developed based on the results from initial interviews which included 100 key respondents. After compiling the questionnaire, content validity (face validity), social desirability response test, and construct validity (convergence and discriminant validity) were conducted. Furthermore, after the validity results were obtained such as our expectations, we conduct the measurement to uncover the effect of transformational leadership toward procedural justice which subsequently affects positive emotions.

\section{Management}

Measurement indicators were developed based on previous studies. Those are conducted by Bass and Riggio (2006) and Yukl (2013) for transformational leadership. As a formative construct, transformational leadership consists of four dimensions, namely, Idealized influence (example: "the interests of the organization are considered as important by a leader"); Intellectual stimulation (exp: "subordinates are always encouraged by leader to solve work problems rationally"); Individualized consideration (exp: "Self-development of subordinates is always improved by a leader"), and Inspirational motivation (exp: "optimistic in performing duties and responsibilities is our leader characteristics").

Furthermore, operational definitions of procedural justice is an example: The rules procedure in our organization are always consistent (Cohen-Charash and Spector (2001); Colquitt et al. (2001)), and the last construct is positive emotions (Morris and Keltner (2000) which operational definition is an example: "the leader treat its staff nicely". Likert scales were used as measurement scales ranging from 1 to 7 . $1=$ Strongly Disagree and $7=$ Strongly Agree.

\section{Instruments Testing}

Content validity (face validity), convergence validity, and discriminant validity (Hair et al., 2010) were also conducted to confirmed measurement indicators validity. Social Desirability Response (SDR) test was also conducted in this study to convince that respondents fill the questionnaire naturally. In the next step, we conduct construct reliability testing which aims to investigate the consistency of the measurement indicators.
Transformational Leadership,

Procedural Justice, and Emotion of Indonesia Civil State Apparatus: Does It Matter?

Figure 1. Research Model. 
According to Chin et al. (1995) that the minimum sample size in research when using variance-based SEM is 5 (five) to 10 (ten) times the number of indicators or 10 times the number of parameters which are contained in the research model. Based on our model, there are four parameters. The meaning of parameter in this regard is

the number of arrows that are from the independent variable to the dependent variable. Thus the minimum sample size for this study is 4 x $10=40$ respondents (Chin et al., 1995)

Hair et al. (2014) argued the greater the sample size used, the better results would be achieved because it will reduce the sampling error. Thus, the sample size in this study was set as many as 650 respondents. we use survey methods to collect the data. Of 700 questionnaires that are distributed by online survey, only 572 are feasible to further analyze. So, the response rate of this study is $88 \%$.

\section{Data Analysis}

Variance-based SEM is used for data analysis and SMART PLS as software. The main reason for using variance-based SEM, because of two constructs with formative indicators, namely transformational leadership and procedural justice. MacKenzie et al. (2005) argued we must notice when using SEM for measuring constructs with formative indicators. This is because many researchers made the mistake of treating formative constructs such as reflective constructs, such as transformational leadership and procedural justice (MacKenzie et al., 2005). Thus, the appropriate SEM used in this measurement is a covariance-based SEM (PLS-SEM). Furthermore, Hair et al

Table 2.

Respondent Characteristics (2011), argued that PLS-SEM can be used for measuring both formative and reflective constructs.

\section{RESULT AND DISCUSSION}

\begin{tabular}{|c|c|c|c|}
\hline Variables & Categories & Sum & $\overline{\text { Percentage }}$ \\
\hline \multirow[t]{2}{*}{ Gender } & Male & 230 & 40.21 \\
\hline & Female & 342 & 59.79 \\
\hline \multirow[t]{5}{*}{ Age } & $25-30$ years & 30 & 5.24 \\
\hline & $31-35$ years & 86 & 15.03 \\
\hline & $36-40$ years & 50 & 8.74 \\
\hline & 41-45 years & 190 & 33.22 \\
\hline & $46-50$ years & 216 & 37.76 \\
\hline \multirow[t]{2}{*}{ Marital Status } & Single & 234 & 40.91 \\
\hline & Married & 338 & 59.09 \\
\hline \multirow[t]{4}{*}{ Job tenure } & Lower than 1 year & 0 & 0 \\
\hline & $1-5$ years & 0 & 0 \\
\hline & $5-10$ years & 248 & 43.36 \\
\hline & Above 10 years & 324 & 56.64 \\
\hline \multirow[t]{4}{*}{ Education } & Senior High School & 80 & 13.98 \\
\hline & Bachelor & 243 & 42.48 \\
\hline & Master & 149 & 26.05 \\
\hline & Doctor & 100 & 17.48 \\
\hline \multirow[t]{6}{*}{ Monthly Income } & IDR $0-1,000,000$ & 0 & 0 \\
\hline & IDR $\quad 1,000,001$ & 200 & 34.97 \\
\hline & $2,500,000$ & & \\
\hline & $\begin{array}{l}\text { IDR 2,500,001 - } \\
5,000,000\end{array}$ & 320 & 55.94 \\
\hline & $\begin{array}{l}\text { IDR 5,000,001 - } \\
10,000,000\end{array}$ & 52 & 9.09 \\
\hline & above IDR $10,000,000$ & 0 & 0 \\
\hline
\end{tabular}

Table 1 showed the characteristic of the respondents in this study. Moreover, we conducted the Socially Desirable Response (SDR) test with the non-paired sample, for five constructs in this study. This test is carried out by distributed questionnaires to civil state apparatus who lived in Jakarta (30 people) and Makassar (30 people). Those who lived in Jakarta received questionnaires with direct questions and others in Makassar were given the questionnaires with indirect questions. By using SPSS with non-parametric statistics, the Mann Whitney test, results show the p-value of each indicator more than 0.05 which means that the two samples (non-paired) come from populations with similar average (mean) or expectations. In other words, the average of respondents' answers from those samples is similar. For more details, it can be seen in Table 2. 


\begin{tabular}{lll}
\hline Constructs & $\begin{array}{l}\text { Measurement } \\
\text { Indicators }\end{array}$ & p-value \\
\hline Procedural Justice & Jp1 & 0.321 \\
& Jp2 & 0.122 \\
Jp3 & 0.111 \\
Jp4 & 0.412 \\
& Jp5 & 0.178 \\
Jp6 & 0.190 \\
\hline Positive Emotion & E1 & 0.333 \\
& E2 & 0.298 \\
& E3 & 0.097 \\
E4 & 0.067 \\
\hline Transformational Leadership & T11 & 0.567 \\
& T12 & 0.666 \\
& T13 & 0.687 \\
& T14 & 0.777 \\
& T15 & 0.311 \\
\hline
\end{tabular}

Transformational

Leadership,

Procedural

Justice, and

Emotion of

Indonesia Civil

State Apparatus:

Does It Matter?

The AVE value of positive emotional construct is 0.586 (more than 0.5) which indicates a good convergence validity (Hair et al., 2014) (see Table 3). AVE values could be seen only for one construct, namely positive emotional. This is because of the construct with reflective indicators. For constructs with formative indicators (transformational leadership and procedural justice), AVE value does not provide any information. Furthermore, the construct reliability values are only owned by the one with reflective indicators, namely positive emotions. The measurement of construct reliability in this study uses Cronbach Alpha $(\alpha)$ and Composite Reliability. Cronbach alpha value is 0.811. As argued by Nunnally (1978) and Kaplan and Saccuzzo (1982) that a good $\alpha$ value for each construct used in basic research is 0.70 to 0.80 . However, according to Baumgartner and Homburg (1996), Composite Reliability is favourable to use for estimating the internal consistency. Based on Table 3, its value is above 0.6 . Thus, the construct reliability used in this study is considered good. Overall, based on Table 3, the results of convergence validity and internal consistency especially for reflective constructs (positive emotions) in this study are good. This is indicated by the AVE value for the construct, which is above 0.5 , which means the convergence validity is good.

\begin{tabular}{llcc} 
Constructs & AVE & Cronbach alpha & Composite Reliability \\
\hline Positive Emotion & 0.581642 & 0.765787 & 0.846720 \\
\hline
\end{tabular}

the validity of formative constructs in this study (procedural justice and transformational leadership) is proved through a bootstrapping process on the Smart PLS program. The results are based on the outer weight output in Table 4. If there are indicators of these formative constructs with a T-statistic value $>1.96$ ( $\mathrm{p}$ value $<0.05)$, then it is a significant construct. Therefore, the construct doesn't meet the construct validity test criteria (Jogiyanto and Abdillah, 2009). If the formative construct does not meet the construct validity test criteria (i.e., there are one or more insignificant indicators), so those cannot be used in further structural model testing.

\begin{tabular}{lll}
\hline Item & $\begin{array}{l}\text { TStatistics } \\
(\mid \mathbf{O} / \text { STERR } \mid)\end{array}$ & p-value \\
\hline e1 <- positive emotion & 9.050871 & 0.000 \\
e2 <- positive emotion & 8.492833 & 0.000 \\
e3 <- positive emotion & 9.093269 & 0.000 \\
e4 <- positive emotion & 5.755835 & 0.000 \\
\hline
\end{tabular}

Table 3. Results of Measurement Models Evaluation with Reflective Indicators 


\section{AMBR}

Table 4.

Results of

Measurement

Models Evaluation with Formative

Indicators

Figure 2.

Structural Model Test

\begin{tabular}{lcc}
\hline t11 -> transformational leadership & 4.170481 & 0.000 \\
t12 -> transformational leadership & 4.763946 & 0.000 \\
t13 -> transformational leadership & 5.970384 & 0.000 \\
t14 -> transformational leadership & 3.535633 & 0.000 \\
t15 -> transformational leadership & 2.035186 & 0.042 \\
\hline jp1 -> procedural justice & 2.669267 & 0.008 \\
jp2 -> procedural justice & 5.762983 & 0.000 \\
jp3 -> procedural justice & 4.736943 & 0.000 \\
jp4 -> procedural justice & 2.567120 & 0.011 \\
jp5 -> procedural justice & 2.499867 & 0.013 \\
jp6 -> procedural justice & 2.016246 & 0.044 \\
\hline
\end{tabular}

Based on Table 4, the outer weight output, T-statistic value for formative construct indicators is $>1.96$ (T-table) or p-value $<0.05$. it could be concluded the formative construct in this research (procedural justice and transformational leadership) can be used in further structural model testing.

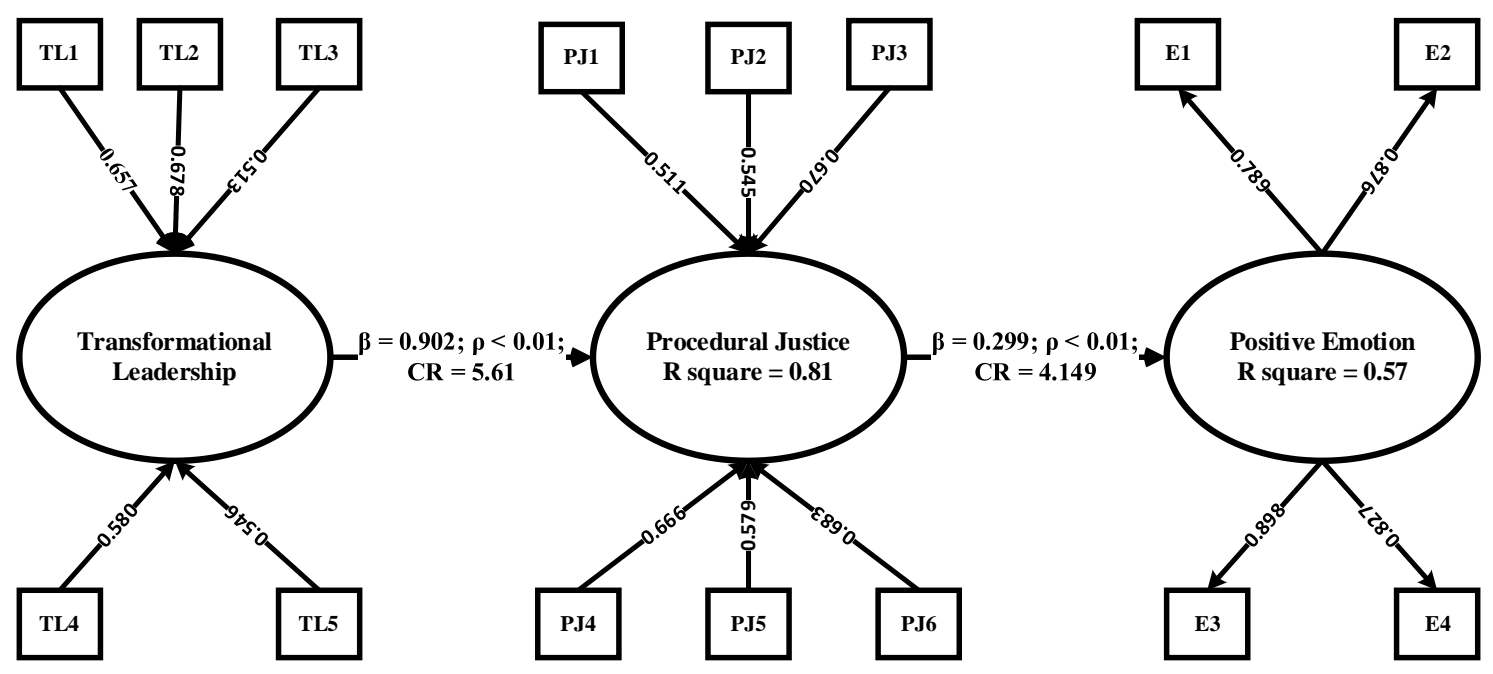

The goodness of fit model in this study is explained in Figure 2. The R-square value for each endogenous variable (procedural and positive emotion) in the model produced by SMART PLS. The R-Square value shows the ability of the independent variables in explaining the variance of the dependent variables. The results of this study indicate that transformational leadership could explain the $81.30 \%$ variance of procedural justice and $0.565 \%$ o variance of positive emotional explained by procedural justice.

As argued by Chin (1998) and Höck and Ringle (2006), the R-square value categories consist of strongly, moderately, and weakly. The R-square value of 0.67 is categorized as strong, 0.33 as moderate, and 0.19 as weak. Thus, the overall research model shows that transformational leadership has a strong ability to explain procedural justice and procedural justice has a strong ability to explain positive emotions.

Furthermore, the value of $\mathrm{f}$ square (effect size) shows the magnitude effect of the predictor on the criterion. Effect size values can be grouped into three categories: weak (0.02), moderate $(0.15)$, and strong $(0.35)$ (Kock, 2013; Hair et al., 2013). The effect size value below 0.02 indicates that the effect of the predictor variable is very weak from a practical perspective even though it has a significant p-value. The results show the effect size of transformational leadership on procedural justice is 0.813 and procedural justice on positive emotions is 0.492 . 
The effect size value of transformational leadership on procedural justice is classified as a large effect size group as well as the procedural justice on positive emotions. Thus, from a practical perspective, transformational leadership has an important role to influence procedural justice, as well as procedural justice toward positive emotions.

Moreover, for the predictive validity model, we used Q-square (usually also called the Stone-Geisser coefficient) as a non-parametric measure obtained through the blindfolding algorithm as argued by Solihin and Ratmono (2013). Models with predictive validity should have Q-square values greater than zero (Solihin and Ratmono, 2013). The results show that this model research has a good predictive validity because the Q-square value is above zero. Overall, the Goodness of Fit $(\mathrm{GoF})$ index of this research model is calculated based on the formula proposed by Tenenhaus et al. (2005)

$$
\text { GoF }=\sqrt{\text { mean communality X mean } R-\text { square }}
$$

Information: mean (average)

From this model research, the average value of communality is 0.734 and R-square is 0.722 , then the Goodness of Fit (GoF) index of the research model is $\sqrt{0.734 X 0.722}=0.728$ As stated by Tenenhaus et al. (2005) that a GoF value above 0.5 can be categorized favourable.

\begin{tabular}{llllll}
\hline & $\begin{array}{l}\text { Estimated } \\
\text { Parameter } \\
\text { Values, } \\
\text { Hypotheses }\end{array}$ & $\begin{array}{l}\text { Critical } \\
\text { Ratio } \\
\text { Standardized } \\
\text { Regression } \\
\text { Coefficients }\end{array}$ & p-value & Direction & Decision \\
\hline $\begin{array}{l}\text { H1: Transformational } \\
\text { leadership has a positive } \\
\text { effect on the perception of } \\
\text { civil servants regarding } \\
\text { procedural justice. }\end{array}$ & 0.902 & 5.614 & 0.000 & Positive & Supported \\
\hline $\begin{array}{l}\text { H2: Procedural justice has a } \\
\text { positive effect on the } \\
\text { positive emotions of civil } \\
\text { servants }\end{array}$ & & & & \\
\hline
\end{tabular}

Table 5 shows SEM estimation and hypothesis testing results. All research hypotheses are supported because the value of Critical Ratio (CR) or t is statistically significant, and has an expected direction as stated in the hypothesis, namely positive direction. The recommended CR value in SEM analysis is more than 1.96 (Garson, 2016) which means a good level of significance. Overall, the leadership perception model can explain and predict organizational justice and organizational justice can explain and predict the positive emotions of civil servants in Jakarta, Makassar, Palu, and Ambon.

The first hypothesis that Transformational leadership has a positive effect on procedural justice perceived by civil state apparatus is supported. This study is consistent with the results of research conducted by Tyler (1986). He argued that procedural fairness has an important role in evaluating the leadership process which in this case is transformational leadership. In this study, transformational leadership could explain and predict perceptions of procedural fairness by $81.30 \%(\mathrm{R} 2=0.813)$.

One important aspect of transformational leadership is that the leader could encourage subordinates to go beyond their interests to achieve the goals of the larger group collectively (group, organization, or country) (Bass \& Riggio, 2006). This concept is following procedural justice, that leaders can increase welfare and group solidarity in the long term (Yukl, 2013; Northouse, 2016). Such transformational leaders could promote procedural justice.

Hypotheses 2 in this study that procedural justice has a positive effect on the positive emotions of civil state apparatus are also supported. This study is also generally in line with the results of research which conducted by Cohen-Charash and Spector (2001). They argued that organizational justice could explain and predict the employee's emotions in an organization. This study shows, the procedural fairness perceived by civil state apparatus in Jakarta, Makassar, Palu, and Ambon could explain and predict they're positive emotions by $56.50 \%$ $(\mathrm{R} 2=0.565)$.

Indonesia civil state apparatus would see procedural fairness if it should meet the following criteria. This is an
Transformational Leadership, Procedural Justice, and Emotion of

Indonesia Civil State Apparatus: Does It Matter?

Table 5. Results of SEM Estimates and Hypotheses Tests 
extent to which it suppresses bias, creates consistent allocations, rely on accurate information, is correctable, represent the concerns of all the recipients, and is based on moral and ethical standards (Budiyanti et al., 2018). As another aspect of civil state apparatus justice perception, procedural justice seems to be a basic requirement. The violation of procedural fairness would elicit negative emotions (Budiyanti et al., 2018).

\section{CONCLUSION}

The model in this study tested using the research background of civil state apparatus which considered as representatives of Indonesia regions, namely Ambon (Eastern Indonesia Region), Palu and Makassar (Central Indonesia Region), and Jakarta (Western Indonesia Region). We use a variety of literature that is integrated to produce a model that connects transformational leadership with procedural justice.

Overall, the results indicate that among civil state apparatus there is a significant relationship between transformational leadership and procedural. Based on the phenomena and our literature review, there is still a lack of empirical testing regarding relationships. Hence, this study supported the view that transformational leadership could have a different effect on organizational justice which is perceived by subordinates based on social exchange relations. Social exchanges occur because of the involvement of individual trust in the relationship regarding their obligations in the long run. Transformational leadership is closely related to perceptions of organizational justice, namely procedural justice. The policies and procedures implemented by the leadership mostly determine the formation of justice perceptions that affect employee emotion.

The effect of procedural justice toward positive emotions, this because positive emotions are often something that results from extraordinary leadership, such as transformational, charismatic, and visionary leadership. Generally, employees in an organization will disappoint and be angry when they received an inappropriate award and feel guilty when they are overrated. Emotions are an important part of organizational life, provide characteristics, and inform processes in organizations. Emotions also have a role in individual communication relating to the main problems in social life. Overall, this study showed the emotional role consequently in the relationship between transformational leadership and procedural justice by Indonesia civil state apparatus.

This study only included respondents in four cities, namely: Ambon, Jakarta, Makassar, and Palu. For further research, it would be better to involve respondents who are located in the whole of Indonesia regions, to generalize the research results properly. This research only looked into the relationship between transformational leadership, procedural justice, and emotions of civil state apparatus. Future research should develop this research for other variables including transactional leadership, distributive and interactional justice which affect positive and negative emotions. Therefore, the result of this study can be generalized, it is comprehensively systematic and theoretic, random, and controllable for understanding and explaining a phenomenon regarding Indonesia civil state apparatus.

\section{References}

Armagan, Y. \& Erzen. E. (2015). Effect of Leadership on Organizational Justice. In E. Karadağ (Ed.), Leadership and Organizational Outcomes Meta-Analysis of Empirical Studies (1st ed., pp. 239-254). Springer. https://doi.org/10.1007/978-3-319-14908-0_15

Barclay, L. J., Skarlicki, D. P. \& Pugh, S. D. (2005). Exploring the Role of Emotions in Injustice Perceptions and Retaliation. Journal of Applied Psychology, 90(4), 629-643.

Barclay, L. J. \& Skarlicki, D. P. (2009). Healing the Wounds of Organizational Injustice: Examining the Benefits of Expressive Writing. Journal of Applied Psychology, 94(2), 511-523.

Barclay, L. J., \& Saldanha, M. F. (2015). Facilitating Forgiveness in Organizational Contexts: Exploring the Injustice Gap, Emotions, and Expressive Writing Interventions. Journal of Business Ethics, 137(4), 699720 .

Bass, B. M. (1985). Leadership and performance beyond expectations. New York: Free Press.

Bass, B. M. (1995). Theory of Transformational leadership redux. The Leadership Quarterly, 6(4), 463-478.

Bass, B. M. (1996). A new paradigm of leadership: An inquiry into transformational leadership. U.S. Army Research Institute for the Behavioral and Social Sciences.

Bass, B. M. \& Avolio, B. J. (1993). Transformational leadership: A response to critiques. In M. M. Chemers \& R. Ayman (Eds.), Leadership theory and research: Perspectives and directions: 49-80. San Diego: Academic Press. 
Bass, B. M. \& Riggio, R. E. (2006). Transformational Leadership. $2^{\text {nd }}$ edition. Mahwah, New Jersey, London: Lawrence Erlbaum Associates, Inc.

Baumgartner, H., \& Homburg, C. (1996). Applications of structural equation modeling in marketing and consumer research. A Review', International Journal of Research in Marketing, 13, 139-161.

Budiyanti, H., Patiro, S. P. S., \& Nurman. (2018). Organizational justice perception of Indonesia civil servants, does it matter? Jurnal Ekonomi Dan Bisnis, 21(2), 333-360.

Cassar, V. \& Buttigieg, S. C. (2015). Psychological contract breach, organizational justice and emotional wellbeing. Personnel Review, 44(2), 217-235.

Chen, H., \& Jin, Y. (2014). The Effects of Organizational Justice on Organizational Citizenship Behavior in the Chinese Context: The Mediating Effects of Social Exchange Relationship. Public Personnel Management, 43(3), 301-313.

Chen, X., He, W., \& Weng, L. (2018). What is Wrong with Treating Followers Differently? The Basis of LeaderMember Exchange Differentiation Matters. Journal of Management, 44(3), 946-971.

Chin, W. W., Marcolin, B. L., \& Newsted, P. (1995). A Partial Least Squares Latent Variable Modeling Approach for Measuring Interaction Effects: Results from A Monte Carlo Simulation Study and Voice Mail Emotion/Adoption Study. Proceedings of The Seventeenth International Conference on Information Systems. Cleveland, Ohio. 21-41.

Chin, W. W. (1998). The partial least squares approach for structural equation modeling. In George A Marcoulides (Ed.), Methodology for business and management. Modern methods for business research (pp. 295-336). Lawrence Erlbaum Associates Publishers.

Chun, J. S., Brockner, J., \& De Cremer, D. (2018). How temporal and social comparisons in performance evaluation affect fairness perceptions. Organizational Behavior and Human Decision Processes, 145, 1-15.

Cohen-Charash, Y.\& Spector, P. E. (2001). The Role of Justice in Organizations: A Meta-Analysis. Organizational Behavior And Human Decision Processes, 86, 278-321.

Colquitt, J. A., Conlon, D. E., Wesson, M. J., Porter, C. O. L. H., \& Ng, K. Y. (2001). Justice at The Millennium: A Meta-Analytic Review of 25 Years of Organizational Justice Research. Journal of Applied Psychology, $86,425-445$.

Crosby, B. C. \& Bryson, J. M. (2018). Why leadership of public leadership research matters: and what to do about it. Public Management Review, 20(9), 1265-1286.

Cropanzano, R., Prehar, C. A., \& Chen, P. Y. (2002). Using social exchange theory to distinguish procedural from interactional justice. Group \& Organization Management, 27(3), 324-351.

Cropanzano, R., Bowen, D. E., \& Gilliland, S. W. (2007). The Management of Organizational Justice. Academy of Management Perspectives, 21(4), 34-48.

Cropanzano, R., Paddock, L., Rupp, D. E., Bagger, J., \& Baldwin , A. (2008). How regulatory focus impacts the process-by-outcome interaction for perceived fairness and emotions. Organizational Behavior And Human Decision Processes, 105, 36-51.

Cropanzano, R. \& Stein, J. H. (2009). Organizational Justice and Behavioral Ethics: Promises and Prospects. Business Ethics Quarterly, 19(2), 193-233.

Deschamps, C., Rinfret, N., Lagacé, M. C., \& Privé, C. (2016). Transformational Leadership and Change: How Leaders Influence Their Followers' Motivation through Organizational Justice. Journal of Healthcare Management, 61(3), 194-213.

Devonish, D., Kouvonen, A., \& Coyne, I. (2012). The Justice-Workplace Health Relationship: The Mediating Role of Emotions. International Journal of Workplace Health Management, 5(2), 88-103.

Dzansi, L. W. (2016). A South African Study Of Influence Of Fairness Of Human Resource Management Practices On Service Quality. The Journal of Applied Business Research, 32(2), 871-882.

Fambrough, M. J. \& Hart, R. K. (2008). Emotions in Leadership Development: A Critique of Emotional Intelligence. Advances in Developing Human Resources, 10(5), 740-758.
Transformation al Leadership,

Procedural

Justice, and

Emotion of

Indonesia Civil

State

Apparatus:

Does It Matter? 
Folger, R. \& Bies, R. J. (1989). Managerial responsibilities and procedural justice. Employee Responsibility and Rights Journal, 2(2), 79-90.

Garson, G. D. (2016). Partial Least Squares: Regression and Structural equation Models, Statistical Associates Blue Book Series. Statistical Publishing Associates.

Gillet, N., Fouquereau, E., Bonnaud-Antignac, A., Mokounkolo, R., \& Colombat, P. (2013). The Mediating Role of Organizational Justice in the Relationship Between Transformational Leadership and Nurses' Quality of Work Life: A Cross-Sectional Questionnaire Survey. International Journal of Nursing Studies, 50(10), 1359-1367.

Gotlib, T. (2011). Multifoci Organizational Justice, Organizational Citizenship Behavior, and Counterproductive Work Behavior: The Mediating Effects of Emotions. Unpublished Dissertation. Melbourne, Florida: Industrial Psychology, Florida Technology Institute.

Greenberg, J. \& Baron, R. A. (2000). Behavior in Organizations (7th ed.). Upper Saddle River, New Jersey: Prentice-Hall.

Guh, W., Lin, S., Fan, C., \& Yang, C. (2013). Effects of Organizational Justice on Organizational Citizenship Behaviors: Mediating Effects of Institutional Trust and Affective Commitment. Psychological Reports, $112(3), 818-834$

Gupta, V. \& Singh, S. (2014). Leadership and Creative Performance Behaviors in R\&D Laboratories: Examining the Mediating Role of Justice Perceptions. Journal of Leadership \& Organizational Studies, 22(1), 21-36.

Hair, J. F., Black, W. C., Babin, B. J., \& Anderson, R. E. (2010). Multivariate Data Analysis. $7^{\text {th }}$ ed. Upper Saddle River, NJ: Pearson Education

Hair, J. F., Hult, T. M., Ringle, C. M., \& Sarstedt, M. (2013). A Primer on Partial Least Squares Structural Equation Modeling. Sage Publications.

Hair, J. F., Sarstedt, M., Hopkins, L., \& Kuppelwieser, V. G. (2014). Partial least squares structural equation modeling (PLS-SEM): An emerging tool in business research. European Business Review, 26(2), $106-121$.

Hair, J. F., Ringle, C. M., \& Sarstedt, M. (2011). PLS-SEM: Indeed a Silver Bullet. The Journal of Marketing Theory and Practice, 19(2), 139-152. https://doi.org/10.2753/MTP1069-6679190202

Höck, M. \& Ringle, C. M. (2006). Strategic networks in the software industry: An empirical analysis of the value continuum. IFSAM VIIIth World Congress, Berlin, 1-15.

Homans, G. C. (1958). Social Behavior as Exchange. American Journal of Sociology, 63(6), 597-606.

Ingraham, P. W., \& Getha-Taylor, H. (2004). Leadership in the Public Sector: Models and Assumptions for Leadership Development in the Federal Government. Review of Public Personnel Administration, 24(2), 95112.

Iqbal, S., Farid, T., Jianhong, M., \& Mehmood, Q. (2018). Cultivating Employees' Communal Relationship and Organizational Citizenship Behavior through Authentic Leadership: Studying the Influence of Procedural Justice. Psychology Research and Behavior Management, 11, 545-555.

Jogiyanto, H. M. \& Abdillah, W. (2009), Konsep dan Aplikasi PLS (Partial Least Square) untuk Penelitian Empiris. Edisi Pertama, Yogyakarta: BPFE

Kaplan, R. W. and Sacuzzo, D. P. (1982). Psychological Testing. Principles, Applications, and Issues, Monterey, CA: Brooks/Cole.

Kim, S., Tam, L., Kim, J., \& Rhee, Y. (2017). Determinants of Employee Turnover Intention: Understanding the Roles of Organizational Justice, Supervisory Justice, Authoritarian Organizational Culture and Organization-Employee Relationship Quality. Corporate Communications, 22(3), 308-328.

Kim, H. \& Kim, J. K. (2015). A cross-level study of transformational leadership and organizational affective commitment in the Korean Local Governments: Mediating role of procedural justice and moderating role of culture types based on competing values framework. Leadership, 11(2), 158-185. 
Kock, N. (2013). Using WarpPLS in E-Collaboration Studies: What If I Have Only One Group and One Condition. International Journal of E-Collaboration, 9(3), 1-12.

Konovsky, M. A. \& Pugh, D. S. (1994). Citizenship behavior and social exchange. Academy of Management Journal, 37, 656-669.

Ledimo, O. (2015). Generational differences in organizational justice perceptions: an exploratory investigation across three generational cohorts. Foundations of Management, 7(129-142).

MacKenzie, S. B., Podsakoff, P. M., \& Jarvis, C. B. (2005). The Problem of Measurement Model Misspecification in Behavioral and Organizational Research and Some Recommended Solutions. Journal of Applied Psychology, 90(4), 710-730.

Mazurkiewicz, M. D. (2009). Understanding The Connection Between Organizational Justice, Emotions, and Employee Strain. Unpublished Dissertation. Fort Collins, Colorado: Department of Psychology Colorado State University.

Moon, K. K. (2017). Fairness at the organizational level: Examining the effect of organizational justice climate on collective turnover rates and organizational performance. Public Personnel Management, 46(2), 118-143.

Morris, M. W. \& Keltner, D. (2000). How Emotions Work: The Social Functions of Emotional Expressions in Negotiations. Research in Organizational Behavior, 22, 1-50.

Namkung, Y., \& Jang, S. C. (2010). Effects of perceived service fairness on emotions, and behavioral intentions in restaurants. European Journal of Marketing, 44(9/10), 1233-1259.

Northouse, P. G. (2016). Leadership: Theory and Practice (7th ed.). United Stated of America: Sage Publication, Inc.

Nunnally, J. C. (1978). Psychometric Theory. (3rd ed.). New York: McGraw-Hill.

Organ, D. W. (1990). The Motivational Basis of Organizational Citizenship Behavior. In B. M. Staw \& L. L. Cummings (Ed.), Research in Organizational Behavior (pp. 43-72). JAI Press.

Pérez-Rodríguez, V., Topa, G., \& Belendez, M. (2019). Organizational justice and work stress: The mediating role of negative, but not positive, emotions. Personality and Individual Differences, 151, 109392.

Pillai, R., Scandura, T. A., \& Williams, E. A. (1999). Leadership and organizational justice: Similarities and differences across cultures. Journal of International Business Studies, 30(4), 763-779.

Podsakoff, P. M., Mackenzie, S. B., Paine, J. B., \& Bachrach, D. G. (2000). Organizational Citizenship Behaviors: A Critical Review of the Theoretical and Empirical Literature and Suggestions for Future Research. Journal of Management, 26(3), 513-563

Robbins, S. P. and Judge, T. A. (2013). Organizational Behavior (15th ed.). Upper Saddle River: Prentice Hall.

Rupp, D. E., Ganapathi, J., Aguilera, R. V., \& Williams, C. A. (2006). The Incubator: Employee Reactions to Corporate Social Responsibility: An Organizational Justice Framework. Journal of Organizational Behavior., 27, 537-543.

Rupp, D. E., Shao, R., Jones, K. S., \& Liao, H. (2014). The utility of a multifoci approach to the study of organizational justice: A meta-analytic investigation into the consideration of normative rules, moral accountability, bandwidth-fidelity, and social exchange. Organizational Behavior And Human Decision Processes, 123, 159-185.

Sharma, D. (2016). When Fairness is Not Enough: Impact of Corporate Ethical Values on Organizational Citizenship Behaviors and Worker Alienation. Journal of Business Ethics, 150(1), 57-68.

Skarlicki, D. P., van Jaarsveld, D. D., \& Walker, D. D. (2008). Getting Even for Customer Mistreatment: The Role of Moral Identity in the Relationship Between Customer Interpersonal Injustice and Employee Sabotage. Journal of Applied Psychology, 93(6), 1335-1347.

Solihin, M. \& Ratmono, D. (2014). Analisis SEM-PLS dengan WarpPLS 3.0. Yogyakarta: Penerbit Andi.

Song, J. H., Kang, I. G., Shin, Y. H., \& Kim, H. K. (2012). The Impact of an Organization's Procedural Justice and Transformational Leadership on Employees' Citizenship Behaviors in the Korean Business Context.
Transformation

al Leadership,

Procedural

Justice, and

Emotion of

Indonesia Civil

State

Apparatus:

Does It Matter? 
Journal of Leadership \& Organizational Studies, 19(4), 424-436.

Strom, D. L., Sears, K. L., \& Kelly, K. M. (2014). Work Engagement: The Roles of Organizational Justice and Leadership Style in Predicting Engagement Among Employees. Journal of Leadership \& Organizational Studies, 21(1), 71-82.

Susanj, Z., \& Jakopec, A. (2012). Fairness Perceptions and Job Satisfaction as Mediators of the Relationship between Leadership Style and Organizational Commitment. Psychological Topics, 21(3), 509-526.

Swanson, R. A. \& Holton III, E. F. (2001). Foundations of Human Resources Development, $1^{\text {st }}$ edition. San Fransisco, California: Berrett-Koehler Publishers, Inc.

Taxman, F. S. \& Gordon, J. A. (2009). DO FAIRNESS AND EQUITY MATTER? An Examination of Organizational Justice Among Correctional Officers in Adult Prisons. Criminal Justice And Behavior, 36(7), 695-711.

Tenenhaus, M., Vinzi, V. E., Chatelin, Y. M., \& Lauro, C. (2005). PLS path modeling. Computational Statistics and Data Analysis, 48(1), 159-205. https://doi.org/10.1016/j.csda.2004.03.005

Thoha, M. (2008). Birokrasi Pemerintah Indonesia di Era Reformasi. Jakarta: Kencana (Prenada media).

Tracy, J. L., Robins, R. W., \& Tangney, J. P. (2007). The Self-Conscious Emotions: Theory and Research, New York, NY: The Guilford Press

Tenenhaus, M., Vinzi, V. E., Chatelin, Y. M., \& Lauro, C. (2005). PLS path modeling. Computational Statistics and Data Analysis, 48(1), 159-205. https://doi.org/10.1016/j.csda.2004.03.005

Thoha, M. (2008). Birokrasi Pemerintah Indonesia di Era Reformasi. Kencana (Prenada media).

Tracy, J. L., R. W. Robins, and J. P. T. (2007). The Self-Conscious Emotions: Theory and Research. The Guilford Press.

Tyler, T. R. (1986). The psychology of leadership evaluation. In H. Bierhoff et al. (Ed.), Justice in social relations. New York, NY: Plenum Press.

Ugaddan, R. G. \& Park, S. M. (2019). Do Trustful Leadership, Organizational Justice, and Motivation Influence Whistle- Blowing Intention? Evidence From Federal Employees. Public Personnel Management, 48(1), 5681.

Unterhitzenberger, C., \& Bryde, D. J. (2019). Organizational Justice, Project Performance, and the Mediating Effects of Key Success Factors. Project Management Journal, 50(1), 57-70.

Van Knippenberg, D., De Cremer, D., \& Van Knippenberg, B. (2007). Leadership and fairness: The state of the art. European Journal of Work and Organizational Psychology, 16, 113-140.

Wang, X., Liao, J., Xia, D., \& Chang, T. (2010). The Impact of Organizational Justice on Work Performance: Mediating Effects of Organizational Commitment and Leader-Member Exchange. International Journal of Manpower, 31(6), 660-677.

Weiss, H. M., Suckow, K., \& Cropanzano, R. (1999). Effects of justice conditions on discrete emotions. Journal of Applied Psychology, 84(5), 786-794. https://doi.org/10.1037/0021-9010.84.5.786

Wu, Y., Sun, I. Y., Chang, C. K.-M., \& Hsu, K. K.-L. (2017). Procedural Justice Received And Given Supervisory Treatment, Emotional States, and Behavioral Compliance Among Taiwanese Police Officers. Criminal Justice And Behavior, 44(7), 963-982.

Yukl, G. (2013). Leadership in Organization (8th ed.). Pearson Education, Inc 